\title{
Tomato Chlorotic Spot Virus ${ }^{1}$
}

\author{
Jane E. Polston, Erin Wood, Aaron J. Palmateer, and Shouan Zhang ${ }^{2}$
}

\section{Introduction}

Tomato chlorotic spot virus (TCSV) is a tospovirus, similar to but distinct from other tospoviruses currently present in Florida, such as Tomato spotted wilt virus (TSWV), Groundnut ringspot virus (GRSV), and Impatiens necrotic spot virus (INSV). Like these viruses, TCSV is transmitted by thrips (Thysanoptera: Thripidae) and is able to replicate in both the vector and the plant. TCSV was first reported in Florida in 2012; however, it may have been in the state for several years because the symptoms in tomato are similar to those of GRSV, which was reported several years earlier (Londoño et al. 2012; Polston and Londoño 2012). TCSV was found for the first time in tomato plants in MiamiDade and Lee Counties in the spring of 2012 (Fig. 1). This

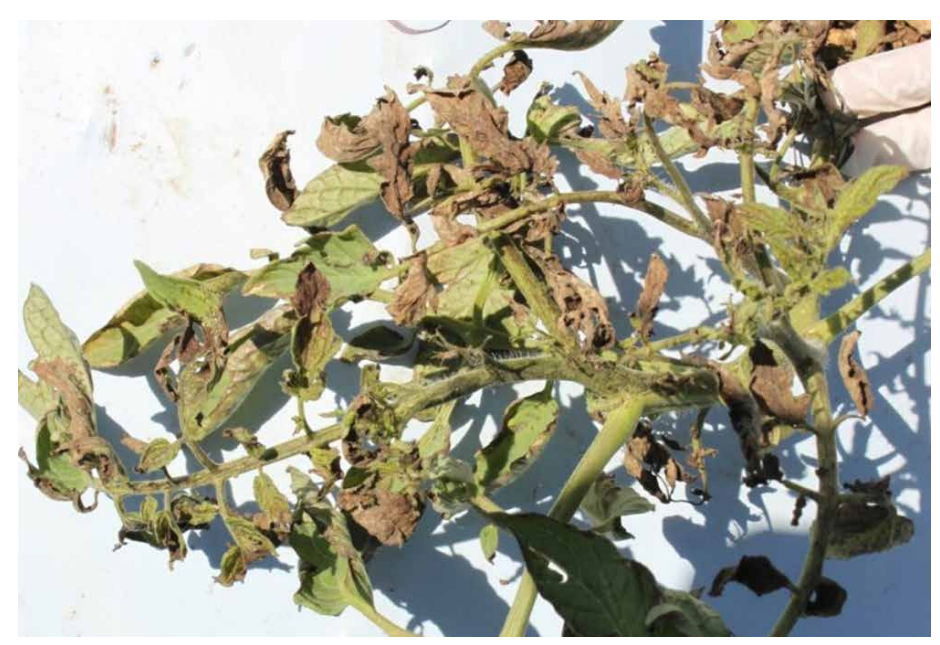

Figure 1. This tomato plant in Miami-Dade County shows symptoms of Tomato chlorotic spot virus, including necrosis, necrotic spots, and leaf distortion.

Credits: S. Zhang is the first known occurrence of the virus in the United States. Prior to 2012, TCSV was only known to occur in Brazil and Argentina. It is not known how this virus was introduced into Florida.

The Tospovirus (family Bunyaviridae) genus of viruses causes diseases of significant economic impact in many crops worldwide. Tospoviruses have the ability to swap whole segments of their genome with other members of the genus, creating new virus isolates with different vectors and modified host ranges, both of which can result in new diseases. Presently, there are eight recognized species belonging to this genus, of which five have been previously reported in the United States (i.e., TCSV, TSWV, GRSV, INSV, and Iris yellow spot virus [IYSV]). Of these, all but IYSV have been previously reported in the state of Florida. More information about tospoviruses can be found in Tospoviruses (Family Bunyaviridae, Genus Tospovirus) (http://edis.ifas.ufl.edu/pp134).

\section{Significance}

TCSV, like other tospoviruses, causes diseases associated with significant losses in overall yield and quality in both agricultural and ornamental crops. TCSV causes extensive necrosis on leaves and fruit, which can significantly reduce yield and fruit quality. As of 2012, TCSV had only been reported to infect tomato plants in Miami-Dade and Lee Counties, causing the onset of severe symptoms that killed newly planted tomatoes, and in an older field, rendered the fruit unmarketable. TCSV is known to cause severe symptoms in plants such as pepper, beans, tobacco, and peanut,

1. This document is PP306, one of a series of the Plant Pathology Department, Florida Cooperative Extension Service, Institute of Food and Agricultural Sciences, University of Florida. Original publication date May 2013. Visit the EDIS website at http://edis.ifas.ufl.edu.

2. Jane E. Polston, professor; Erin Wood, graduate student; Aaron J. Palmateer, assistant professor; and Shouan Zhang, assistant professor; Plant Pathology Department, Tropical Research and Education Center, University of Florida Institute of Food and Agricultural Sciences, Homestead, FL 33031 
and in ornamental crops such as lisianthus. The potential exists for TCSV epidemics in these crops in Florida. The geographic distribution of TCSV in Florida is not known beyond Miami-Dade and Lee Counties. Considering the widespread distribution of thrips, TCSV has the capacity to significantly expand.

\section{Symptoms}

Table 1 summarizes symptoms associated with TCSV infection and lists known host species. TCSV-infected tomatoes develop necrotic lesions of variable size, easily recognized necrotic and chlorotic spots, and ringspots on leaves, stems, petioles, flowers, and fruit. Symptoms are similar to those of GRSV and, to a lesser extent, some isolates of TSWV (Figs. 1 and 2). Although apparently less common, chlorotic spots and ringspots may form prior to or at the same time as necrotic lesions. Following the onset of these symptoms, wilting and bronzing of the infected plant may occur. TCSV infections in young tomato plants may result in severe stunting and eventually death. Fruit from infected plants may show necrotic ringspots, necrotic spots, and distortion, rendering them unmarketable (Fig. 3).

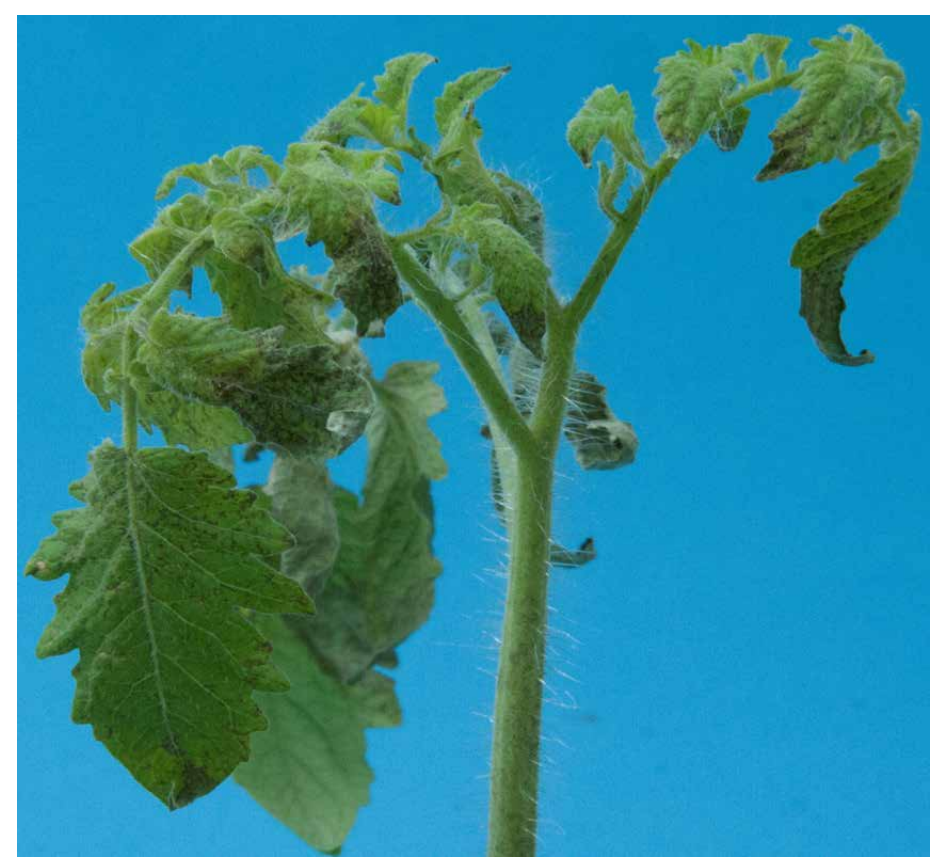

Figure 2. Tomato cv. 'Sweetheart' 2 weeks after inoculation with Tomato chlorotic spot virus showing necrosis and necrotic spots on leaves, leaf curling, and leaf distortion.

Credits: J. E. Polston

Symptoms in pepper plants include severe stunting, necrotic spots, necrotic ringspots, and severe leaf deformation (Fig. 4). Fruit from infected pepper plants can be deformed and present ringspots and irregular coloring (Fig. 5).

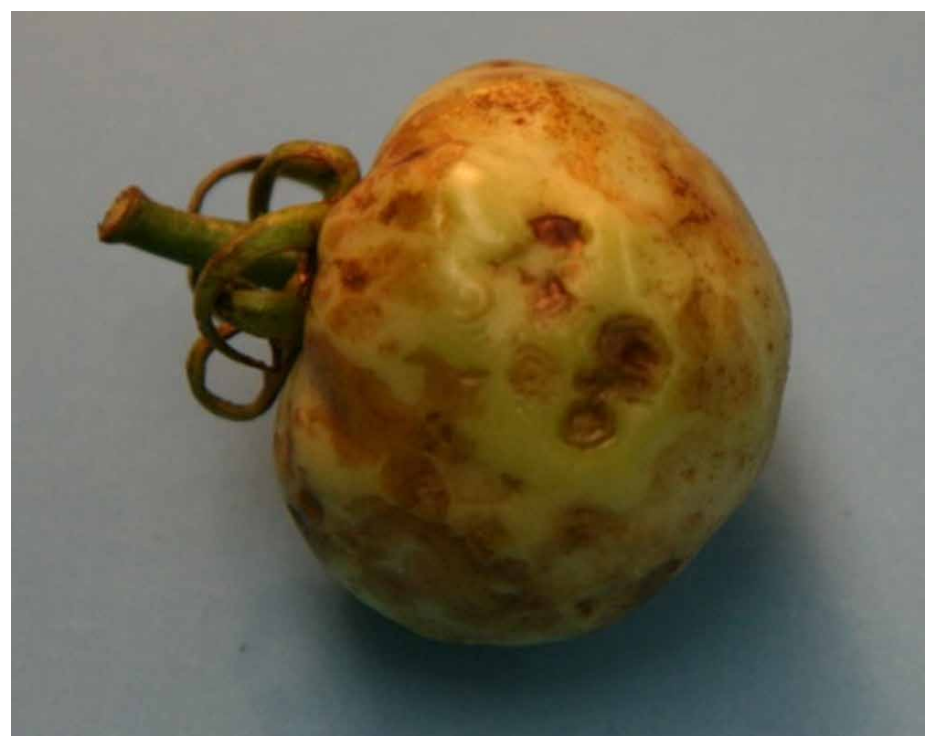

Figure 3. Fruit from a tomato plant infected with Tomato chlorotic spot virus showing deformation and discoloration.

Credits: J. E. Polston

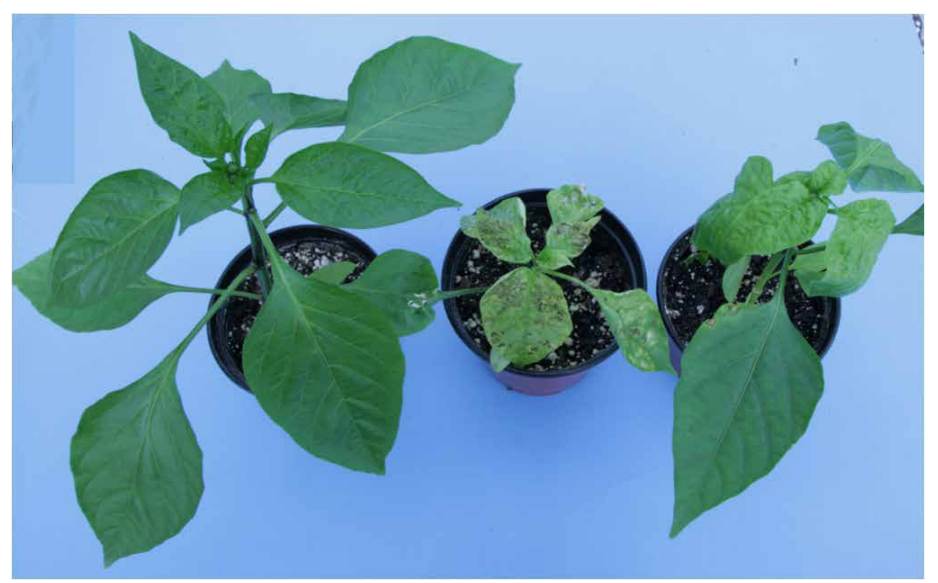

Figure 4. Left: healthy pepper; right: pepper plants inoculated with Tomato chlorotic spot virus showing symptoms of necrosis, necrotic spots, necrotic ringspots, leaf distortion, and stunting. Credits: J. E. Polston

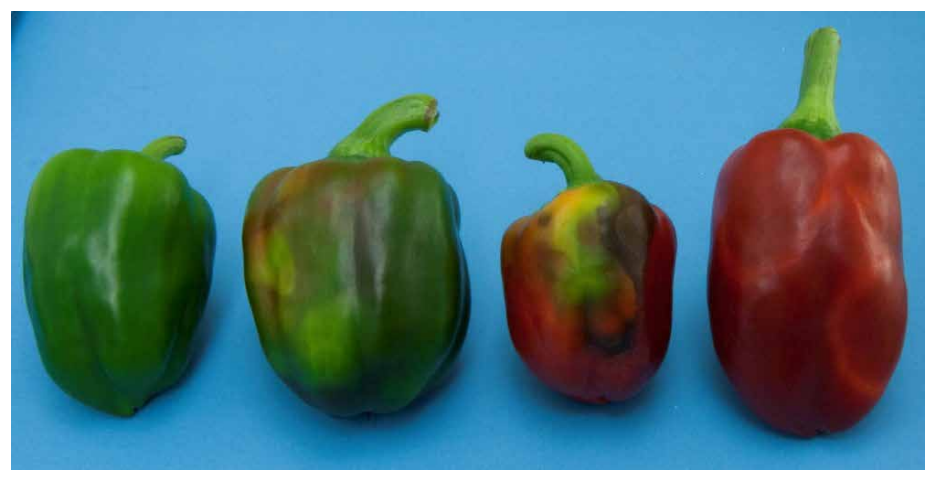

Figure 5. Fruit from pepper plants (Capsicum annuum 'California Wonder') inoculated with Tomato chlorotic spot virus.

Credits: J. E. Polston 


\section{Host Range}

Since TCSV has been recognized in Florida only recently, little is known about its host range with respect to Florida crops and wild plant species. Table 1 presents a summary of known hosts and symptoms associated with TCSV infection. As more research is conducted on TCSV, the host range is likely to expand.

\section{Transmission}

TCSV, like other members of the Tospovirus genus, is vectored by certain thrips species (Thysanoptera: Thripidae) in a persistent and propagative manner. As with other tospoviruses, TCSV is only acquired by the larval ( $1^{\text {st }}$ and $2^{\text {nd }}$ instar) stages of the thrips vector as they feed on infected plants. The virus replicates in the thrips throughout the insects' development, remaining in the thrips through molts. Once the thrips are mature, the adult thrips are capable of transmitting the virus for the remainder of their lives. Adult thrips are the only ones capable of transmission and, as they are the only stage capable of flight, they are well suited to spread TCSV among plants.

To date, only limited studies have been conducted on TCSV transmission. TCSV is known to be transmitted by three species of thrips: common blossom thrips (Frankliniella schultzei), western flower thrips (F. occidentalis), and flower thrips (F. intonsa) (Wijkamp et al. 1995). Interestingly, TCSV and TSWV are not transmitted at similar efficiencies by the same thrips (Table 2). The most efficient TCSV vectors are the dark form of $F$. schultzei followed by $F$. occidentalis. These relative transmission efficiencies are the opposite of those of TSWV, which is transmitted at a much higher rate than TCSV by F. occidentalis and at a lower rate by F. schultzei.

It is probably not a coincidence that TCSV detections increase with population density increases of the dark form of F. schultzei in Miami-Dade County. For many years, F. schultze $i$ was present in tomato fields at low population densities; however, over the last 4 years, populations of this thrips species have increased to the point that it is now considered one of the major insect pests of tomato. More specific information about this thrips is available in Common Blossom Thrips, Frankliniella schultzei Trybom (Insecta: Thysanoptera: Thripidae) (http://edis.ifas.ufl.edu/ in860).

\section{Detection}

TCSV detection from field or greenhouse samples can be accomplished with serological and molecular assays. TCSV can be detected by immune-dipsticks, available from AgDia, Inc. and BIOREBA AG. These assays are easy to conduct and provide results in less than 30 minutes. However, because of similarities in the coat proteins of tospoviruses, they are not specific and will detect other tospoviruses as well, such as TSWV and GRSV. For larger numbers of samples, it is more cost-effective to purchase commercially available ELISA kits. This method requires very little specialized laboratory equipment and provides reliable results within 24-48 hours. However, as with dipsticks, ELISA kits are unable to differentiate between TCSV, TSWV, and GRSV. A third assay option is PCR, which can distinguish among these viruses using virus-specific primers or broad-spectrum primers followed by sequencing. While PCR is more specific, its use requires specialized laboratory equipment and training. Some commercial and university diagnostic laboratories are equipped to conduct these assays, and results are available within a few days. For many users this option is costly, but it avoids the complications of running in-house PCR assays.

\section{Management}

Once a plant has become infected with a virus, it cannot be cured; therefore, effective management practices should focus on using host plant resistance, reducing sources of inoculum, and suppressing vector populations and their movement.

Although there may be other thrips vectors, TCSV is most likely being transmitted by F. schultzei and F. occidentalis in Florida. Unfortunately, the lack of knowledge about alternate hosts for TCSV in Florida makes it impossible to know what plants may be serving as reservoirs for TCSV. Therefore, comprehensive recommendations for TCSV management cannot be made at this point. However, recommendations that apply to TSWV management may be effective in managing TCSV.

Recent studies suggest that some of the host genes conferring resistance to TSWV in tomato may provide resistance to TCSV. Selection of TSWV-resistant tomato cultivars could help decrease yield losses from TCSV. This may also be true for TCSV management in pepper, although specific studies are not currently available. More detailed recommendations are available in Managing Thrips and Tospoviruses in Tomato (http://edis.ifas.ufl.edu/in895). 


\section{Recommendations}

- Select TSWV-resistant or tolerant cultivars.

- Use virus-free transplants.

- Remove weed reservoirs from around the production area.

- Apply appropriate insecticides to reduce thrips populations.

- Apply systemic acquired resistance (SAR) elicitors to reduce symptom expression.

- Use UV-reflective mulch to repel thrips.

- Rotate crop plantings; where possible, isolate susceptible crops through the use of non-host barrier crops to prevent virus transmission between fields.

- Intercrop with fast-growing (non-host) crops to make habitat unappealing to thrips.

The same control techniques described above could also be applicable in greenhouse settings, with the additional recommendations to use thrips-proof netting and/or ultraviolent-absorbing light plastics where possible, as well as yellow sticky cards to capture thrips.

\section{References}

Adkins, S., T. Zitter, and T. Momol. 2013. Tospoviruses (Family Bunyaviridae, Genus Tospovirus). PP-212. Gainesville: University of Florida Institute of Food and Agricultural Sciences. http://edis.ifas.ufl.edu/pp134.

de Avila, A. C., P. de Haan, M. L. L. Smeets, R. de O. Resende, R. Kormelink, E. W. Kitajima, R. W. Goldback, and D. Peters. 1993. "Distinct Levels of Relationships Between Tospovirus Isolates.” Arch. Virology 128: 211-227.

Londoño, A., H. Capobianco, S. Zhang, and J. E. Polston. 2012. "First Record of Tomato Chlorotic Spot Virus in the U.S." Tropical Plant Pathology 37: 333-338.

Polston, J. E., and A. Londoño. 2012. "A New Virus for Florida Tomatoes." In Proc. of the Florida Tomato Institute, edited by M. Ozores-Hampton and C. Snodgrass, 27-29. Naples, FL: Florida Tomato Institute.

Wijkamp, I., N. Almarza, R. Goldback, and D. Peters. 1995. "Distinct Levels of Specificity in Thrips Transmission of Tospoviruses." Phytopathology 85 (10): 1069-1074. 
Table 1. Known hosts of Tomato chlorotic spot virus

\begin{tabular}{|c|c|c|c|}
\hline Family & Scientific name & Common name & Symptoms \\
\hline \multirow[t]{3}{*}{ Asteraceae } & Lactuca sativa & Lettuce & Dwarfing, mosaic, chlorotic and necrotic ringspots \\
\hline & Cichorium endivia & Escarole & Mosaic, chlorotic and necrotic ringspots \\
\hline & Emilia sonchifolia & Lilac tasselflower & Mosaic \\
\hline Balsaminaceae & Impatiens spp. & Impatiens & Yellowing and vein clearing \\
\hline \multirow[t]{4}{*}{ Fabaceae } & Arachis hypogaea & Peanut & Mosaic \\
\hline & Phaseolus vulgaris & Common bean & Vein clearing \\
\hline & Pisum sativum & Pea & Mosaic, bronzing, wilting \\
\hline & Vigna unguiculata & Cowpea & Mosaic, leaf distortion \\
\hline Gentianaceae & Eustoma russellianum & Lisianthus & Ringspots, necrosis, leaf deformation, dwarfing \\
\hline \multirow[t]{2}{*}{ Orchidaceae } & Epidendron spp. & Epidendron orchid & Extensive necrosis of leaves leading to leaf abscission \\
\hline & Phalaenopsis spp. & Phalaenopsis orchid & Large yellow chlorotic ringspots on inoculated leaves \\
\hline \multirow[t]{5}{*}{ Solanaceae } & Capsicum annuum & Pepper & Mottling, leaf distortion, dwarfing, apical necrosis, callousing on the stem \\
\hline & Datura stramonium & Datura & Mottling, leaf distortion, dwarfing, apical necrosis, plant death \\
\hline & Nicotiana tabacum & Tobacco & Vein clearing, mosaic, leaf distortion \\
\hline & Solanum lycopersicum & Tomato & Mottling, bronzing, necrotic spots, necrosis on stems and petioles \\
\hline & Physalis floridana & Husk tomato & Mottling, veinal necrosis \\
\hline
\end{tabular}

Table 2. Transmission of Tomato chlorotic spot virus (TCSV) and Tomato spotted wilt virus (TSWV) by four species of thrips

\begin{tabular}{|l|l|l|l|}
\hline \multicolumn{2}{|c|}{ Thrips } & \multicolumn{2}{c|}{ Transmission efficiency } \\
\hline Scientific name & Common name & TCSV & TSWV \\
\hline $\begin{array}{l}\text { Frankliniella schultzei } \\
\text { (dark form) }\end{array}$ & $\begin{array}{l}\text { Common blossom thrips (tomato } \\
\text { thrips) }\end{array}$ & $37.5 \%$ & $13.7 \%$ \\
\hline Frankliniella occidentalis & Western flower thrips & $27.6 \%$ & \\
\hline $\begin{array}{l}\text { Frankliniella schultzei } \\
\text { (light form) }\end{array}$ & $\begin{array}{l}\text { Common blossom thrips } \\
\text { (tomato thrips) }\end{array}$ & $5.9 \%$ & $66.0 \%$ \\
\hline Frankliniella intonsa & Flower thrips & & $2.3 \%$ \\
\hline Thrips tabaci & Onion thrips & $0.7 \%$ & \\
\hline (Source: Wiljkamp et al. 1995) & & $0.0 \%$ & $31.8 \%$ \\
\hline
\end{tabular}

